\title{
The Impact of Technological Change on New Trade: Evidence from the Container Revolution
}

\author{
Daniel M. Bernhofen \\ Zouheir El-Sahli \\ Richard Kneller
}

CESIFO WORKING PAPER No. 6069

CATEgory 8: TRAde Policy

SEPTEMBER 2016

An electronic version of the paper may be downloaded

- from the SSRN website: Www.SSRN.com

- from the RePEc website: Www.RePEc.org

- from the CESifo website: www.CESifo-group.org/wp 


\title{
The Impact of Technological Change on New Trade: Evidence from the Container Revolution
}

\begin{abstract}
This paper exploits exogenous features of the 1960s/70s container revolution to estimate the impact of the introduction of refrigerated containers (or reefers) on new trade of temperature sensitive products. Our identification strategy is justified by a historical narrative which suggests that the containerization of bilateral trading routes was exogenous to the growth of trade in 'reefer commodities' and stimulated trade in non-traditional (exotic) non-bulk commodities such as pharmaceuticals, photo film and sensitive instruments. Our study combines previously collected data on variations in the container usage on bilateral trade routes with newly collected data on temperature sensitivity and applies them to 5-digit product level trade flows. Our benchmark estimates suggest that the introduction of reefer containers caused an increase in the likelihood of new trade in temperature sensitive products of 9\% during 1968 and 1973 and 13\% between 1968 and 1978.
\end{abstract}

JEL-Codes: F130, N700.

Keywords: trade in temperature-sensitive products, extensive margin, impact of refrigerated containers.

Daniel M. Bernhofen*

School of International Service

American University

4400 Massachusetts Ave NW

USA - Washington, DC 20016-8071

dbernhof@american.edu

\author{
Zouheir El-Sahli \\ Department of Economics \\ Lund University \\ Lund / Sweden \\ Zouheir.El-Sahli@nek.lu.se
}

\author{
Richard Kneller \\ School of Economics \\ University of Nottingham \\ Nottingham / United Kingdom \\ richard.kneller@nottingham.ac.uk
}

*corresponding author 


\section{Introduction}

Recent research in international trade has examined the emergence of trade in products that have not been traded before, which has been referred to as the new goods or extensive margin. One branch of this literature - such as Feenstra (1994), Hummels and Klenow (2005) and Broda and Weinstein (2006) - has made progress in developing empirical methods for assessing the new goods margin. Another branch has examined changes in the extensive margin during specific trade liberalization experiences or periods of structural transformations, like Arkolakis et al. (2008), Mukerji (2009), Debaere and Mostashari (2010) and Kehoe and Ruhl (2013). ${ }^{2}$ Neglected within this literature has been the role of technological change in stimulating new trade.

Most would agree that technological change is a main driver of trade and economic activity. However, one of the key identification challenges for estimating its impacts is that its path is often gradual and the prospect of future trade is itself a driver of technological change. This paper examines the effects of one of the most significant technological changes in transportation technology during the $20^{\text {th }}$ century: the container revolution. Specifically, we exploit exogenous features of the 1960s/70s container revolution to estimate the impact of the introduction of refrigerated containers (or reefers) on the growth of trade of temperature sensitive products along the extensive margin, defined as the occurrence of trade in new products to new destinations ${ }^{3}$.

Our identification strategy is justified by our historical narrative, described in section 2, which suggests that the containerization of bilateral trading routes was exogenous to trade in 'reefer commodities' and stimulated new trades in temperature sensitive products (henceforth TSP). TSP comprise of chilled and frozen food items but also manufactured products such as pharmaceuticals, chemicals, and camera film and processed food such as chocolate and other confectionary. Transportation of such goods is distinct from general cargo, requiring refrigeration to maintain temperatures and guarantee the integrity of the products involved, in particular over longer journeys (Arduino and Parola, 2010).

We argue that the expected future growth of international trade in a TSP would not have been included in the calculations to containerize a bilateral trading route because containers are the low-cost method to ship TSP only for small volume cargo. An anticipation of large future growth in trade in any one of these products would instead have justified investment in an alternative transport technology, reefer ships. This is well documented within the reefer industry and is apparent both for traditional reefer commodities, where trade is not fully containerized even today, and commodities that became traded in large volumes, such as the kiwi fruit. Growth in the extensive margin of kiwi fruit trade from New Zealand in the late 1960s occurred by exploiting the availability of established container-routes and reefer-containers, but switched to reefer ships in the mid-1980s when volumes became large. We infer from this narrative that, from the perspective of any TSP, containerization on bilateral trading routes was as good as randomly assigned. Thus, the causal effect of containerization on the extensive margin can, for this group of products, be accurately estimated.

Our study combines previously collected data on variations in the container usage in bilateral trade routes with newly collected product level data on variations in temperature sensitivity. To determine which products are temperature-sensitive we rely on information from an engineering study by Rytter (2009) into the transport of temperature sensitive goods in Europe. Within that study, 4-5 digit ISIC codes are classified on a scale of 1 to 4 according to their temperature sensitivity. This index takes into account the various temperature demands that a product requires during transportation, such as the temperature and temperature range a product will tolerate, but also factors such as their potential for contamination by and of other materials. Data

\footnotetext{
${ }^{2}$ See also Felbermayr and Kohler (2010) who have examined entrance into the GATT/WTO and Flam and Nordstrom (2006) who have studied the impact of the single currency on the extensive margin.

${ }^{3}$ In previous work (Bernhofen et al (2016)), we exploited cross-sectional and time variation in countries' adoption of port or railway container facilities to estimate the effects of the container revolution on total bilateral trade. Rua (2014) examines the determinants of the diffusion of container technology.
} 
on the containerization of bilateral trade routes and the degree of containerizability at the product level is taken from Bernhofen et al. (2016). ${ }^{4}$ These data are then applied to explain variations in SITC 5-digit bilateral trade flows taken from the UN Commodity Trade (Comtrade) database.

Our estimates suggest that the introduction of reefer containers increased the likelihood of new trade in temperature sensitive products. These results are consistent with a causal effect of containerization on the extensive margin of trade in temperature-sensitive products based on empirical verification of an identification strategy of parallel trends between future containerizes (treatment group) and non-containerizers (control group). In terms of magnitudes, our benchmark estimates suggests an increase in the extensive margin of $9 \%$ between 1968 and 1973 and 13\% between 1968 and 1978. Our findings are robust with respect to varying the treatment windows of containerization, different definitions of temperature sensitivity and product containerizability and other robustness considerations. In order of magnitude, our estimates are a bit higher, but quite comparable to Debaere and Mostashari (2010) who found that an increase in the extensive margin of between $5 \%$ and $12 \%$ from US tariff reductions.

The next section of the paper provides background information on reefer trade, trade in TSP and reefer containers. Section 3 describes the data sources. Section 4 contains the empirical specification and tests of parallel trends. While section 5 discusses the benchmark estimates and robustness exercises, section 6 includes some extensions.

\section{The impact of the container revolution on trade in temperature sensitive products}

International trade of refrigerated cargo dates back to the $19^{\text {th }}$ century when in 1877 the steamers Le Frigorifique and Paraguay first successfully carried frozen meat from Argentina to France. By the 1880s, the emergence of the reefer industry created new exports of beef, mutton and lamb from South America, Australia and New Zealand to Europe. The resulting decline in the price of protein relative to the price of carbohydrates benefitted European consumers (Mokyr, 1990, p.141). The next 80 years witnessed the emergence of worldwide trade in traditional reefer commodities like frozen meat (carcasses), dairy produce (mainly butter), citrus fruits, deciduous fruits ${ }^{5}$ and bananas. These trades were characterized by their large volumes and in the case of bananas, their year-round harvest periods. Shipping of these products occurred in specialized vessels - reefer ships - and by specialist tramp shippers rather than the liner shipping lines used for most general cargo ${ }^{6}$.

On the eve of the container age, the shipping sector was a fairly segmented industry experiencing only relatively small technological changes. ${ }^{7}$ As pointed out in Bernhofen et al. (2016, p.39), containerization started out as a private endeavor by the shipping lines because port authorities were unwilling to invest in what was initially perceived to be a 'niche technology'. Because international trade in traditional reefer commodities was characterized by large scale economies that facilitated the emergence of specialized ports capable of storing refrigerated cargo prior to the transit via land transport, owners of the reefer shipping fleet do not appear to have recognized the potential that containerization might have on expanding the range of products that they could carry. For example, the shipping consultants Drewry (1990, p.14-15) writes: "Even viewed on an historical basis, the wholesale containerization of deep sea trade has actually had little impact upon the market share of the major (reefer) tramp operators". Initially, there was a debate of whether temperature sensitive cargoes such as bananas could be carried in containers. More importantly, it was the prevailing view that insulating each

\footnotetext{
${ }^{4}$ Bernhofen et al. (2016) construct the bilateral container adoption variable from various editions of the Containerization International Yearbook. Information on the degree of containerizability of a product group is based on a 1968 study the German Engineers Society.

${ }^{5}$ These are apples, pears, and grapes.

${ }^{6}$ There were also part-refrigerated ships carrying part-refrigerated cargoes in 'season'.

${ }^{7}$ Among other factors, the resistance of organized labor to labor-saving technological change played a significant role in hampering innovation. See El-Sahli and Upward (2015) for evidence on the container-induced dramatic decline of port worker employment and estimates on the long-run impact of containerization on dock workers in Britain.
} 
box rather than the whole ship was an inefficient use of available space and would therefore increase shipping costs.

\section{The emergence of reefer containers}

Up to the mid-1960s innovation in reefer shipping was undertaken by equipment manufacturers in order to serve the specialized reefer market (Drewry, 1990). For the shipping lines the relatively short distances, combined with limited market size limited the incentive to innovate (Drewry, 1990). However, the introduction of reefer containers that resulted from the container revolution had some unexpected consequences in the form of facilitating the growth of new products. To understand this impact, it is important to note that reefer containers come into two forms: porthole and integrated reefers. Porthole containers are containers that are connected to a central refrigeration unit in the ship. This type of container is more appropriate for large volume, homogeneous cargoes. Porthole containers require shore side infrastructure to insure continuous temperature control. Integral reefer containers have their own machinery and only require an external supply of electricity to operate at sea or on land. Typically, integral reefer containers are more expensive than porthole containers but they are more suitable for small and high value shipments.

Of primary interest in this paper is the use of integral reefer containers for the transportation of small volumes of new and difficult to transport commodities outside the traditional reefer fleet. ${ }^{8}$ According to Drewry (1990) the shipping of new types of TSPs in integral reefer containers was an important part of the growth of total trade in TSPs over the 1970s and 1980s and distinct from trade in traditional reefer commodities. For this group of products, the advent of containerization meant that their international trade became cost-effective for the first time, but only as part of larger containerized cargoes of non-TSPs. For example, electric points for integral reefer containers were available on almost all liner containerships by the late 1970s. These slots were available only in small quantities and were not necessarily, and according to Drewry (1983) not very often, used for perishable goods as they could also be used for containerized general cargo. As the shipping consultants Drewry write "where they are used, it is often for minor reefer cargoes" (Drewry, 1983, p13), of the type we are interested in here. The infrequency with which reefer slots were used demonstrates the small volume in which much of this trade in TSPs occurred and indicates that trade in these products would not by themselves have justified the large capital investments needed to adopt the container.

That the realized volumes of trade in TSPs were small does not by itself preclude the possibility that the growth in TSP trade was expected to have been large and it was this expectation that justified the investment in the container technology. The anticipation of future growth of trade in TSPs would however have justified an expansion of the specialized reefer shipping fleet and not containerization. For larger volume trade specialist reefer ships were favored. ${ }^{9}$

Figure 1 Illustrates the differences in the average transports costs using reefer containers compared to reefer ships. Because transporting cargo via reefer ships requires hiring an entire ship, fixed costs are high and result in relatively high average costs for small trade volumes. Differences in temperature requirements across products also meant that it was not possible to pool together different TSPs and share these costs. Hence transportation via reefer ships is cost effective for large trade volumes in single product cargos. In contrast, transportation via reefer containers has lower fixed costs, but higher variable costs compared to reefer-ships or even fully-refrigerated container ships (Drewry, 1983). As a consequence, when trade volumes were small,

\footnotetext{
${ }^{8}$ The first purpose-built reefer container vessels were introduced to the Europe-Australia trade in 1969, and incorporated central refrigeration machinery to provide cold air to over 300 containers. According to evidence from the Containerisation International Yearbook for 1974 the first fully-cellular refrigerated vessel entered service in 1973 (the Remuera operated by Australian National Line between Europe and Australia/New Zealand).

${ }^{9}$ Shippers sought ways to avoid the expense of refrigerating cargo. Over shorter-distances ro/ro (roll-on, roll-off) ships with fans to ventilate rather than refrigerate cargo were used. There were also developments over this time period in coating products or irradiating it.
} 
average costs were lower for reefer containers as part of general cargo compared to shipping using specialist reefer ships. For large volume, frequent, bilateral trade, average costs for shipping by reefer containers were higher compared to hiring an entire reefer ship. ${ }^{10}$ So the introduction of reefer containers reduced the average trade costs of shipping small amounts of temperature-sensitive products. We test whether this encouraged the emergence of international trade in TSPs that had not been traded previously.

\section{Figure 1: Average shipping costs of using reefer containers versus reefer ships}

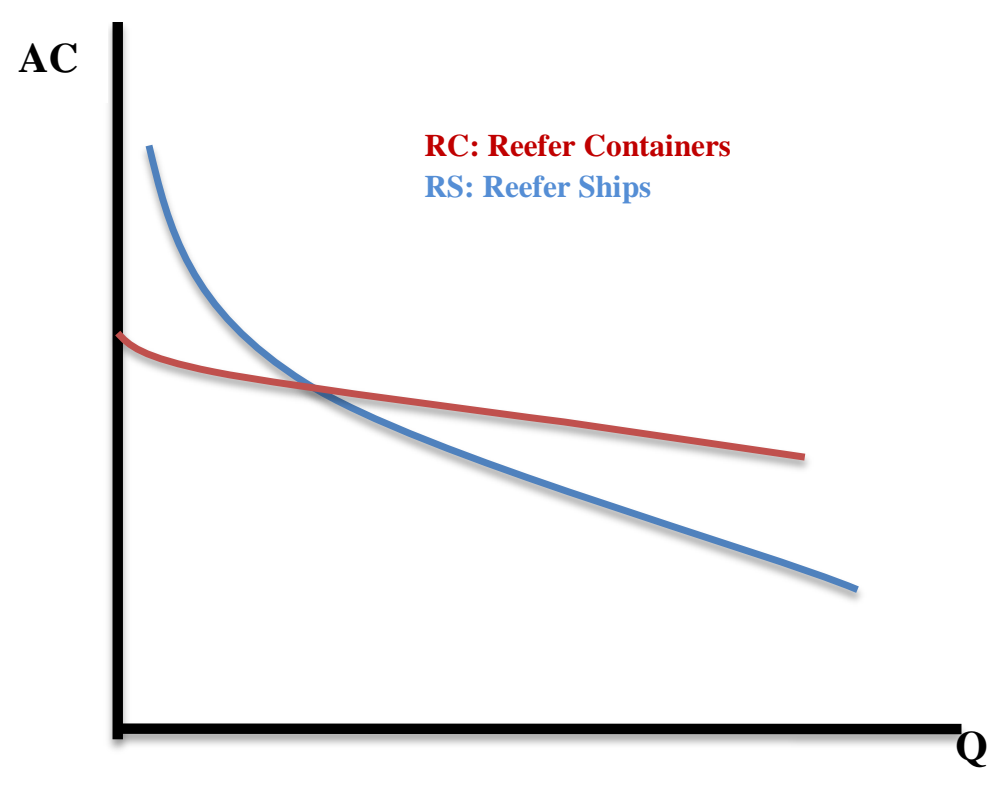

An illustrative example: new trade in Kiwis and between New Zealand and Europe

Within the reefer industry, trade in kiwifruits is often held up as an example, not only of the new trades that were made possible by containerization, but also the cost-advantages of the transportation of TSPs using specialized reefer-vessels as volumes grew. Known as the Chinese gooseberry until their name change in the early 1960s, the kiwifruit is very temperature sensitive, requiring close temperature management to lengthen its shelf life; temperature has to be kept between -0.5 and 0.5 degrees. Kiwifruits were first harvested for the domestic market in New Zealand from the early 1940s and they were exported in small volumes to countries such as the UK and Australia in 1952-53 and to the US in 1962. In the early 1970s export volumes amounted to only a few hundred trays (each containing between 33-42 fruits) ${ }^{11}$. It also has a short harvest period, primarily in May-July, and therefore was not suited to dedicated liner shipping, either by reefer vessels or by whole reefercontainer ships. Following successful marketing campaigns export volumes grew quickly and reached 45 million trays by 1987 (Drewry, 1990). ${ }^{12}$ These initial shipments were carried by the container lines of Europe, exploiting the availability of container vessels on long established container routes for trade in general cargo (Drewry, 1990). By the 1984 volumes of kiwifruit exports from New Zealand had grown sufficiently such that the economies of scale now favored conventional reefer ships and within a few years the majority of trade was

\footnotetext{
${ }^{10}$ Consistent with this Drewry (1983) report that the smallest class of full reefer-ships $(60,000-199,000$ cu.ft) were inactive for twice as long as the next category of size $(200,000-299,000$ cu.ft).

${ }^{11}$ A standard 20ft container can accommodate 2,088 trays (12 pallets each with 174 trays) (Drewry, 1988).

${ }^{12}$ Marketing occurred by the Kiwifruit Export Promotion Committee, which was formed in 1970 and the Kiwifruit Authority, which was formed in 1977. See Skallerud and Olsen (2011).
} 
carried in this way. ${ }^{13}$ This was partly for reasons of cost but also to ensure sufficient access to the required shipping capacity.

As the kiwifruit example shows, the decision to adopt the container to transfer temperature sensitive products on the route between New Zealand and Europe occurred as a result of the economies of scale and efficiencies offered by the already existing containerization of general cargo on the same route. The new trade in kiwifruit was therefore contingent on the frequency and size of vessels on a liner-container route. The containerization of a bilateral trade route, was from the perspective of trade in TSP, an exogenous event. We exploit this to identify the effect of containerization on the extensive margin of trade in TSP using noncontainerized trade routes as a counterfactual.

Figure 2 provides more systematic evidence of new trade between New Zealand (ZL) and Europe ${ }^{14}$ in temperature sensitive products. NZ-European trade is chosen as this set of countries includes the early and deep adopters of the container as a technology and represents distant countries for which international shipping is particularly important. In Figure 2 we follow the methodology of depicting changes in the growth of new trade as suggested by Kehoe and Ruhl (2013) and apply it to imports into Europe from NZ between 1965 (one year before the container is first used in international trade) and $1975 .{ }^{15}$ Figure 2 is constructed by decomposing the 195 traded products between NZ and Europe into 10 equal trade share categories based on their 1965 trade values (as indicated by the horizontal red line at 0.1). This means that 188 products accounted for just $10 \%$ of the import value in 1965 and 7 products accounted for the remaining $90 \%$ of imports in that year. The blue bars in Figure 2 depict then the changes in the import shares in each category between 1965 and 1975 and reveal that the share of the least traded products increased to $21 \%$ by $1975 .{ }^{16}$

Figure 2: The growth of the extensive margin of TSP European imports from New Zealand (1965 vs 1975)

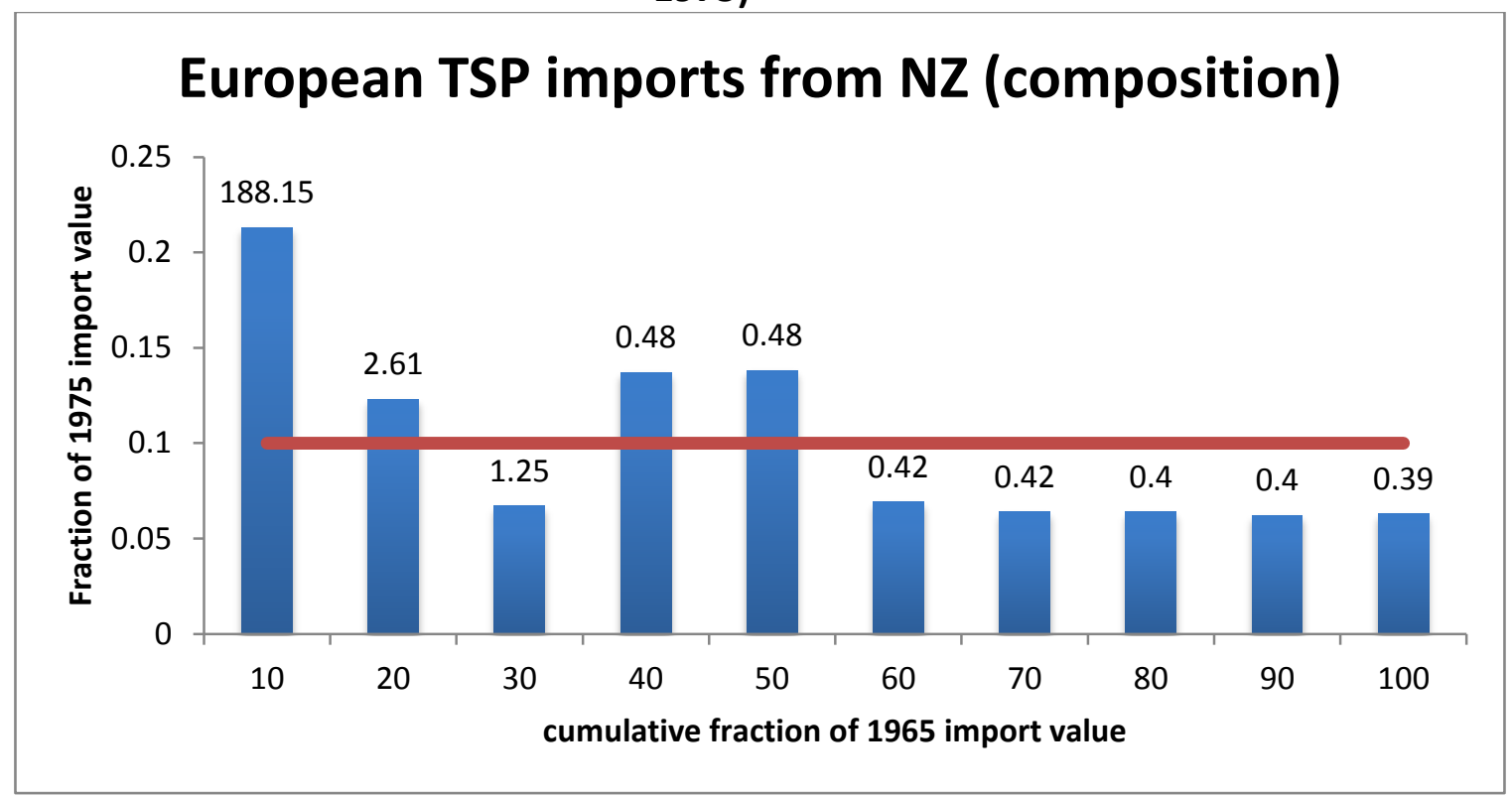

\footnotetext{
${ }^{13}$ According to Drewry (1988) there were 9 shipments of kiwifruits from New Zealand using reefer-ships in 1985,23 in 1986 and 42 in 1987.

${ }^{14}$ In the context of our example, Europe is comprised of the UK, France, Germany, Netherlands, Belgium, Ireland, Italy, Spain, Portugal, Austria, Switzerland, Sweden, Norway, Denmark, Finland, and Greece.

${ }^{15}$ We actually take the average of trade flows between 1963 and 1965 and compare them to the average product trade flows between 1973 and 1975.

${ }^{16}$ The value of all TSP imports increased from \$34 million (7.8\% of total trade) to $\$ 90$ (10\% of total trade) between 1965 and 1975 .
} 


\section{Alternative technologies}

A threat to the identification of the effects of containerization on the extensive margin of trade comes from the development of alternative technologies that are now widely used in the delivery of TSP, namely aircraft. According to data from Hummels (2007) the share of airfreight in the value of US imports was $8.1 \%$ in 1965 , reached $12.0 \%$ in 1970 and $19.8 \%$ by 1985 . For exports the increases were even more dramatic increasing from $11.9 \%(19.5 \%)$ in 1965 (1970) to 36.3\% in 1985. Declines in the cost of air freight along with technological changes that have allowed aircraft to fly further and faster have ensured that over time high-value, low-weight products have switched from being transportation by ocean to air (Hummels, 2007; Gordon, 1990). TSP such as pharmaceuticals, exotic fruits, cut flowers have such characteristics and airfreight plays an important role in their delivery today.

This was not the case over the sample period that we study however. To a large extent this would appear to be driven by technical considerations of the reefer boxes used for airfreight. The variance in temperatures, a critical variable in the transportation of TSP, is typically much greater when using airfreight, increasing the need for temperature control systems. During the 1970s and 1980s airfreight typically relied on pallets and covered pallet systems (known as igloos). The adoption of integrated cooling systems was rare and much later than for ocean shipping. As described in Drewry (1990) "The contrast between the extreme precision of modern reefer containers and the rough and ready control systems of the airfreight industry present a vivid contrast". While it is difficult to find quantitative evidence to support this view it would seem that air freight affected reefer trades only for relatively short journeys where temperature could be controlled by insulation rather than refrigeration. Of interest it is documented that airfreight did stimulate trade in some noncontainerizable TSPs, namely live animals, over this time period. We return to this issue in section 5.

\section{Data construction and sources}

Because we are interested in explaining variations in the emergence of new bilateral trade flows, we use disaggregated commodity trade data from the UN Commodity Trade (UN Comtrade) database which records bilateral commodity trade at the SITC 5-digit product level going back to 1962. Because OECD countries dominated world trade in our period of concern and also were the pioneers in adopting the container technology ${ }^{17}$, we restricted our sample to country-pairs where at least one of the parties is an OECD country. ${ }^{18}$

As made clear in the discussion of the reefer industry our identification of the effects of treatment by containerization might be considered valid for a particular sub-set of potential trade flows. To investigate products that are sensitive to temperature variation we rely on information from an engineering study by Rytter (2009) in which products (ISIC) are classified on a scale of 1 to 4 according to their temperature sensitivity. Product categories which are not temperature sensitive are assigned an index value of 1 and a value of 4 is assigned to product categories which are most temperature sensitive. For the purpose of our empirical analysis, we define temperature sensitive products (TPS) as those which are either sensitive (index value 3) or very sensitive (value 4). ${ }^{19}$ Given our interest in new, small volume trade flows that were facilitated by the advent of the container we exclude traditional reefer products such as meat, fish and bananas which were carried by specialist reefer shipping lines. We further restrict the set of products to include only those that can be carried by the container ${ }^{20}$. This excludes trade in products such as live animals from the analysis.

\footnotetext{
${ }^{17}$ The 23 OECD countries in 1988 are: Australia, Austria, Belgium, Canada, Denmark, Finland, France, Germany, Greece, Iceland, Ireland, Italy, Japan, Luxembourg, Netherlands, New Zealand, Norway, Portugal, Spain, Sweden, Switzerland, Turkey, the UK and the US.

${ }^{18}$ The dataset reports trade flows of around 200 countries (including 23 OECD countries) of which we have containerization information on 157. There are 1,371 products under the 5-digit SITC (Rev. 1) product classification. For some products, the 4-digit product code would be the most disaggregated level. For these products, the 4-digit product classification is used.

${ }^{19}$ In total there are 253 products that are classified as temperature sensitive or very sensitive, 812 products that are not temperature sensitive (value 1) and 306 products that are somewhat sensitive (value 2 ).

${ }^{20}$ These are products classified as containerizable and of limited containerizability in Bernhofen et al. (2016).
} 
Information about of the degree of containerizability at the product level and data on the containerization of bilateral trade routes is taken from Bernhofen et al. (2016). Gravity control variables stem from CEPII ${ }^{21}$.

\section{Empirical specification, initial evidence and test for parallel trends}

\subsection{Empirical specification}

Building on the historical evidence that TSPs were inconsequential to the decision to containerize along a bilateral trading route we aim to estimate the effect of the use of container technology on the emergence of new bilateral trading relationships at the product level using a difference-in-difference framework. Our dependent variable is binary and measures the conditional import status of a product $k$ at time $t$ in country $i$ from a potential trading partner $j$. The underlying regression equation for our baseline estimations is taking the following form:

$$
\left(y_{\{i j k, t+1\}} \mid\left(y_{\{i j k, t\}}=0\right)\right)=\beta_{1}+\beta_{2} \operatorname{cont}_{\{i j, t+1\}}+X_{\{i j, t+1\}}^{\prime} \lambda+\alpha_{1 i, t+1}+\alpha_{2 j, t+1}+\alpha_{3 k}+\epsilon_{\{i j k, t+1\}}
$$

Conditional that country $i$ does not import product $k$ from country $j$ at time $t$, (i.e. $y_{\{i j k, t\}}=0$ ), at time $t+1$, country $i$ can either import product $k$ (i.e. $\mathrm{y}_{\{\mathrm{ijk}, \mathrm{t}+1\}}=1$ ) from country $j$ or not (i.e. $\mathrm{y}_{\{\mathrm{ijk}, \mathrm{t}+1\}}=0$ ). The estimated equation becomes then a linear probability model where one estimates the conditional probability of new imports of temperature-sensitive products.

Our main explanatory variable of interest is the binary container technology variable $\operatorname{cont}_{\{i j, t+1\}}$, which takes the value 1 if both countries $i$ and $j$ have entered the container age by the period $t+1$, and 0 otherwise. Though the construction of the explanatory variable we compare the effects of treatment, which is the adoption of container technology by both countries $i$ and $j$, relative to a counterfactual, which we capture using trade in containerizable TSPs amongst pairs of countries that had not adopted container technology by $t+1$, which we chose as 1973. The counterfactual therefore includes trade in TSPs from countries that never amended port or rail infrastructure to handle container shipments. We also restrict ourselves to early adopters of the container, on the basis that electricity points for integrated reefer boxes were ubiquitous across the container ships by the late 1970s and therefore future trade in TSPs could have been used as a motive to adopt the container the greater is the length of time after 1969.

We initially define 'treatment' as the bilateral adoption of the container before 1973 but test the robustness to the use of the bilateral adoption of the container before 1978 . We use 1968 as the precontainerization time period as this is the year before the first documented use of (porthole) reefer boxes on container ships. When expressed in this way we now require that the growth of the extensive margin of trade amongst late adopters of the container represent a suitable counterfactual for early adopters. The availability of trade data prior to the containerization era allows us to test this assumption of parallel trends and we report the results from this test in section 4.3. We explore alternative estimation strategies, including the use of an alternative control group later in the paper.

The matrix $X_{\{i j k, t+1\}}^{\prime}$ contains all of our control variables. These include the standard bilateral gravity variables like distance, common language, border, colonial links, common currency and policy variables like free trade agreements (FTAs), and GATT membership. We also control for trade preferences since many of the products imported into the EU were agricultural and were therefore subject to trade preferences. Finally, we also include a full set of origin (j), destination (i) as well as product (k) dummies to control for unobserved country and product characteristics that might affect growth of the extensive margin.

\footnotetext{
${ }^{21}$ www.cepii.fr
} 


\subsection{Initial evidence}

Table 1 compares the differential growth paths of new product trade between containerized and noncontainerized country pairs employing different treatment time windows for container adoption (1966-73 and 1966-1978). The numbers in the Table pertain to the 639,957 country-product triads that were not traded in 1968. The right-hand column of Table 1 portrays the benchmark growth of new trade for all countries. It shows that in 1973 37,638 country-product triads were traded, which represent 5.9\% of the non-traded triads in 1968. By 1978 the number of new product-country trades had grown to 52,087 (8.1\%) and to 57,394 (9\%) by 1983.

Columns (2) and (3) split up the country-product triads between containerized and non-containerized countries and the percentages pertain to the non-traded triads in 1968 for each group. ${ }^{22} \mathrm{~A}$ comparison between the two columns reveals significant differences in the growth of new trade for both treatment windows. For example by 1973 just 3.1\% of the possible country-product triads were being traded by country pairs that did not containerize, versus $15.8 \%$ of possible triads that did containerize. By 1978 this figure was $21.3 \%$ for containerized countries and $4.4 \%$ for non-containerized country pairs and this rises further still by 1983 . The growth of the extensive margin of trade would therefore appear to have been more rapid amongst country pairs that adopted the container technology.

Similar patterns are observed when we define treatment for a longer time period, namely as those countries that containerize between 1966 and 1978 and study the growth of the extensive margin between 1968 and 1978 (1983). Now we find that of the 639,957 non-traded product-country combinations in 1968, $8.1 \%(9.0 \%)$ become traded by 1978 (1983). These new trades are disproportionately made up of countries that containerized between 1966 and 1978. Of the 639,957 observations with zero trade in 1968, 304,696 (47.6\%) were by countries that containerized in the future. Out of these observations for future containerizers, $13.6 \%$ (15.0\%) become traded by 1978 (1983), compared to $3.2 \%$ (3.5\%) for countries that did not containerize by 1978 (1983).

\section{Table 1: New trades}

\begin{tabular}{l|ccc}
\hline & $\begin{array}{c}\text { Containerized } \\
\text { Countries }\end{array}$ & $\begin{array}{c}\text { Non-Containerized } \\
\text { Countries }\end{array}$ & Total \\
\hline Containerize 1966-1973 & & & \\
$\mathbf{1 9 7 3}$ Newly traded (\%) & $22,209(15.8 \%)$ & $15,429(3.1 \%)$ & $37,638(5.9 \%)$ \\
$\mathbf{1 9 7 8}$ & $29,887(21.3 \%)$ & $22,200(4.4 \%)$ & $52,087(8.1 \%)$ \\
$\mathbf{1 9 8 3}$ & $32,517(23.2 \%)$ & $24,877(5.0 \%)$ & $57,394(9.0 \%)$ \\
\hline Containerize 1966-1978 & & & \\
$\mathbf{1 9 7 8}$ Newly traded (\%) & $41,490(13.6 \%)$ & $10,597(3.2 \%)$ & $52,087(8.1 \%)$ \\
$\mathbf{1 9 8 3}$ & $45,724(15.0 \%)$ & $11,670(3.5 \%)$ & $57,394(9.0 \%)$ \\
\hline
\end{tabular}

\subsection{Parallel trends}

Difference-in-difference (DID) estimates are invariably scrutinized based on the extent to which the control group represents the valid counterfactual. Key to this approach is the identifying assumption of parallel trends. Given our interest in growth of the extensive margin, we compare the new trades that occurred between 1964 and 1968 using the fact that this time period was prior to the advent of the reefer container in integrated or porthole form. We can then compare the effect of future containerization on the probability of new trades over this earlier time period.

\footnotetext{
${ }^{22}$ For example, for the treatment window of 1966-1973, the 639,957 non-traded product triads are split between 140,239 for containerized countries and 499, 718 for non-containerized countries. So the percentages of new trade in columns 2 and 3 in the upper part of Table 1 pertain to these numbers.
} 
Before reporting on more formal evidence using future treatment, we consider a growth comparison on the raw data similar to what we have done in the previous section. We consider import triads that were not traded in 1964 and whether they were imported or not by 1968, separating observations according to whether they containerize at some point in the future (any point between 1966 and 1983). The raw data imply that of the 530,106 not traded country-product combinations in 1964, 26,510 become traded in $1968 .{ }^{23}$ Of these 5,389 were by country-pairs that did not both adopt the container in the future and 21,121 by country-pairs that did. This represents a very similar proportion of the country-product pairs in each group; $4.2 \%$ for noncontainerizers as compared to $5.3 \%$ for future containerizers. The similarity of the growth of trade along the extensive margin in the pre-containerization time period can be put in further context by noting that the rate of growth of the extensive margin for untreated observations in the period after 1968 was also between 3\% and 5\% (see column 3 in Table 1).

In Table 2 we test this more formally by running a regression using future containerization as a potential explanation for the import status of products in 1968 that were not being imported in 1964. In specification 1 in Table 2 we restrict the sample to include bilateral-observations that containerize between 1966 and 1973 and use pairs that had not containerized by 1973 as the counterfactual. In specification 2 we define future treatment as bilateral containerization between 1966 and 1978 and use the remaining noncontainerized pairs as the counterfactual. These exactly match the treatment periods and counterfactual groups we report in the main regression results further below. Conditional on origin, destination country and product effects to control for other determinants of the growth of the extensive margin of trade including GDP of the origin and destination countries, we find no significant difference between future containerizers and noncontainerizers over the period from 1964 to 1968. To put this differently, future containerization does not help to predict the international trade of temperature sensitive products in the era before reefer containers became available in any form. In regression 1 the point estimate on the future containerization variable is positive, but it is small $(0.4 \%)$ and not statistically significant at conventional levels. In regression 2 the results are even more emphatic, the point estimate is $0.03 \%$. We conclude from this exercise that the assumption of parallel trends would appear reasonable for treatment that we study and that late adopters are a valid counterfactual for early adopters.

Table 2: Parallel Trends

\begin{tabular}{l|cc}
\hline Regression no. & $\mathbf{1}$ & $\mathbf{2}$ \\
Not traded in: & $\mathbf{1 9 6 4}$ & $\mathbf{1 9 6 4}$ \\
Dep. Var. Import Status in: & $\mathbf{1 9 6 8}$ & $\mathbf{1 9 6 8}$ \\
Containerization date & $\mathbf{1 9 6 6 - 1 9 7 3}$ & $\mathbf{1 9 6 6 - 1 9 7 8}$ \\
\hline \hline & & \\
Cont $_{i j}$ & 0.004 & -0.0003 \\
& $(0.007)$ & $(0.006)$ \\
\hline $\boldsymbol{N}$ & & \\
$\boldsymbol{R}$-squared & 213,238 & 530,106 \\
Controls & 0.153 & 0.120 \\
& Importer, exporter, & Importer, exporter, \\
& product & product \\
\hline
\end{tabular}

Standard errors in parentheses

${ }^{*} p<0.05,{ }^{* *} p<0.01, * * * p<0.001$

Dependent variable is the log of import of product $k$ in year $t$ from country $j$ into country $i$. Sample restricted to temperature sensitive and containerizable products. All regressions restrict the sample to only include country-product combinations for which there was no trade in 1968. All regressions control for FTA, GATT membership, border, common language, distance, colonial links, trade preferences. Dummies: $i$ stands for importer, $j$ for exporter, $k$ for product. We cluster standard errors by country-pair (ij).

\footnotetext{
${ }^{23}$ Note that the number of country-product triads not traded in 1964 is lower than in 1968 because of the larger number of country-pair trading relationships in 1968 (3315 country pairs) compared to 1964 (2887 country pairs).
} 


\section{Econometric Results}

\subsection{Baseline estimates}

Table 3 contains our benchmark estimates of equation (1) using our two different treatment windows of 1966-1973 and 1966-1978 for new trade in containerizable TSP occurring in 1973, 1978 and 1983 (time points $t+1$ ) conditional that there was no trade in 1968 (time point $t$ ). As mentioned earlier, we chose 1968 as the pre-containerization time period as this is the year before the first documented use of reefer boxes on container ships. In regressions (1)-(4), the treatment group contains all country pairs where both countries adopted the container technology by 1973. While the first three regressions don't differentiate how long the technology has been in use regression (4) introduces a variable that counts the number of years since a countrypair adopted the technology. For ease of exposition, Table 3 contains only the estimated coefficients pertaining to our container variable.

The estimated coefficient in regression (1) of Table 3 suggests that compared to non-containerized country pairs, previously non-traded containerizable TSP (in 1968) were more likely to be traded in 1973 if both countries had adopted the container by this date. The estimate of the container coefficient is statistically significant and the size suggests that the probability of new trade is increased by $8.7 \%$. As we gave argued in Section 2, because trade in TSP would not have justified investment in the container the timing of adoption can be viewed as exogenous and therefore this can be viewed as the causal effect of this particular technological change on the country-product extensive margin of trade.

In regressions (2) and (3) the observation years for new trade $(t+1)$ are moved to 1978 and 1983, respectively. Because our benchmark year for no trade remains fixed at 1968, we are looking now at the emergence of new trade over time periods of 10 and 15 years. These specifications take of the notion that the spread of the use of reefer containers for carrying TSP would take some time. We would anticipate that the effect of the container should become larger as it became more deeply embedded in the transport infrastructure of countries. In each of these regressions we exclude observations for countries that containerized after 1973 (in regression 2 this relates to country-pairs that containerized between 1973 and 1978 and in regression 3 the 10-years between 1973 and 1983). The rationale for this is to constrain the set of observations within the counterfactual to include only the very late adopters of the container (regression 2) and non-containerized pairs of countries (regression 2 and 3). Hence, in regression 2 we study whether TSP that were not traded in 1968 were more likely to be traded in 1978 by countries that had both adopted the container by 1973. In regression 3 we consider whether those products were more likely to be imported or not in 1983.

The estimated coefficients in regressions 2 and 3 continue to be statistically significant and, not surprisingly, rise in magnitude. It grows to $12.6 \%$ in regression 2 and $45.5 \%$ in regression 3 , which is consistent with the view that the benefits from containerization grew as countries experimented with the technology and further innovations in reefer technologies, such as integral-reefers, were introduced. Assuming that newly created trades are equal to the average value of trade created for containerized pairs and the point estimates from regressions 1 to 3, this would suggest that the additional trade caused by the container was \$0.19billion if we use the results from regression $1^{24}, \$ 1.23$ billion from regression 2 and $\$ 6.4$ billion from regression 3.

Because we are not aware of another study that aims to estimate the effects of technology change on new trade, we can't compare the size of our estimates relative to the effects of other technological changes. As we mentioned earlier, the empirical trade literature has primarily focused on the effects of trade policy changes, like tariff reductions. Using disaggregated US bilateral trade data, Debaere and Mostashari (2010) have found that US tariff changes increased new US trade by about 5\% for 1989-1999 and 12\% for 1996-2006.

\footnotetext{
${ }^{24}$ We calculate this as $0.088 * 140239 * \$ 15,625$ for regression $1 ; 0.127 * 140239 * \$ 69,006$ for regression 2 ; and $0.452 * 140239 * \$ 63,388$ for regression 3.
} 
Although our data domain is broader on the country-pair dimension but narrower on the product dimension than Debaere and Mostashari (2010) our estimates in regression 1 and especially in regression 2 are quite similar to the findings of these authors. We view this as confirmation that our estimates are quite plausible.

Our specifications 1-3 ignore the fact that some bilateral pairs were treated for a longer amount of time than others. This restriction would appear unwarranted given the evidence from regressions 2 and 3 that the effects of containerization increase with time. In regression 4 we capture this by introducing a variable that counts the number of years since the bilateral adoption of the container alongside the $0 / 1$ bilateral container variable. The results from this regression indicate that the adoption of the container increases the extensive margin of trade by some $7 \%$ but that this effect increases the longer the time period the route has been containerized. The increase in the probability of importing TSPs in 1973 is estimated to be 7.6(=7+0.6)\% for observations where the container was adopted in 1972 , compared to $11.2(=7+4.2) \%$ for those countries that had both adopted the container for 7 years.

Thus far we have taken a rather conservative approach and limited the timing of treatment (the bilateral adoption of the container) to occur before 1973. In regressions 5-7, the treatment window is extended to include country-pairs that have both containerized by 1978. Regression 7 is the counterpart to regression 4 where we account for the number of years since both countries in a country-pair adopted the container technology. Overall the results are appear to remain quite robust when using the wider treatment window with the estimates in regressions (5), (6) and (7) almost mirroring the estimates in regressions (1), (3) and (4) respectively.

Table 3: Benchmark Results

\begin{tabular}{|c|c|c|c|c|c|c|c|}
\hline $\begin{array}{l}\text { Regression no. } \\
\text { Not traded in }\end{array}$ & $\begin{array}{c}1 \\
1968\end{array}$ & $\begin{array}{c}2 \\
1968\end{array}$ & $\begin{array}{c}3 \\
1968\end{array}$ & $\begin{array}{c}4 \\
1968\end{array}$ & $\begin{array}{c}5 \\
1968\end{array}$ & $\begin{array}{c}6 \\
1968\end{array}$ & $\begin{array}{c}7 \\
1968\end{array}$ \\
\hline $\begin{array}{l}\text { Dep. Var. Import } \\
\text { Status in year: }\end{array}$ & 1973 & 1978 & 1983 & 1973 & 1978 & 1983 & 1978 \\
\hline $\begin{array}{l}\text { Containerization } \\
\text { date between }\end{array}$ & $1966-1973$ & $1966-1973$ & $1966-1973$ & $1966-1973$ & 1966-1978 & $1966-1978$ & 1966-1978 \\
\hline $\operatorname{cont}_{i j, t}$ & $\begin{array}{c}0.087 * * * \\
(0.011)\end{array}$ & & & $\begin{array}{c}0.070 * * * \\
(0.012)\end{array}$ & $\begin{array}{c}0.089 * * * \\
(0.011)\end{array}$ & & $\begin{array}{c}0.077^{* * *} \\
(0.011)\end{array}$ \\
\hline $\operatorname{cont}_{i j, t-5}$ & & $\begin{array}{c}0.126^{* * *} \\
(0.015)\end{array}$ & & & & $\begin{array}{c}0.447^{* * *} \\
(0.020)\end{array}$ & \\
\hline $\operatorname{cont}_{i j, t-10}$ & & & $\begin{array}{c}0.455^{* * *} \\
(0.020)\end{array}$ & & & & \\
\hline $\begin{array}{l}\text { No. years since } \\
\text { cont. began }\end{array}$ & & & & $\begin{array}{c}0.006^{* * *} \\
(0.001)\end{array}$ & & & $\begin{array}{c}0.003 * * * \\
(0.001)\end{array}$ \\
\hline$N$ & 603,753 & 448,580 & 264,689 & 603,753 & 603,753 & 419862 & 603,753 \\
\hline$R$-squared & 0.155 & 0.221 & 0.270 & 0.155 & 0.202 & 0.242 & 0.203 \\
\hline Controls & $\begin{array}{c}\text { Importer, } \\
\text { exporter, } \\
\text { product }\end{array}$ & $\begin{array}{l}\text { Importer, } \\
\text { exporter, } \\
\text { product }\end{array}$ & $\begin{array}{l}\text { Importer, } \\
\text { exporter, } \\
\text { product }\end{array}$ & $\begin{array}{l}\text { Importer, } \\
\text { exporter, } \\
\text { product }\end{array}$ & $\begin{array}{l}\text { Importer, } \\
\text { exporter, } \\
\text { product }\end{array}$ & $\begin{array}{l}\text { Importer, } \\
\text { exporter, } \\
\text { product }\end{array}$ & $\begin{array}{l}\text { Importer, } \\
\text { exporter, } \\
\text { product }\end{array}$ \\
\hline
\end{tabular}

Standard errors in parentheses

$* \mathrm{p}<0.05, * * \mathrm{p}<0.01, * * * \mathrm{p}<0.001$

Sample restricted to temperature sensitive and containerizable products. All regressions restrict the sample to only include country-product combinations for which there was no trade in 1968. All regressions control for free trade agreements (FTA), GATT membership, border, common language, distance, colonial links, trade preferences. Dummies: $i$ stands for importer, $j$ for exporter, $k$ for product. We cluster standard errors by country-pair (ij).

The evidence presented thus far suggests that the container stimulated new trades in TSP between pairs of countries that had adopted the technology. The historical narrative on the history of the container 
strongly suggests that this was particularly important for small volume trade. Trade costs could be spread across the costs of filling a container compared to the hiring of a reefer ship. This would tend to suggest that new trades in containerized TSP were likely to be smaller than new trades between pairs of countries that were not containerized, at least initially. We investigate this in Table 4 where we run the same regressions as in Table 3 except for measuring the dependent variable as the value of trade for products that were not traded in 1968 but become traded by 1973, 1978 and 1983.

The result from regression 1 shows that the initial value of trade was smaller between containerized countries compared to the non-containerized pairs that form the counterfactual, although the difference is small. Of the products that were not traded in 1968, but which become traded in 1973 the value of trade was $0.45 \mathrm{log}$ point lower for containerized pairs. That the difference is small might suggest that these were highervalue products compared to new trades between non-containerized countries.

There is also evidence that these new trades grew quickly compared to the counterfactual. By 5-years later the value of trade in containerized pairs was statistically similar to those for non-containerized pairs (regression 2), but by 10 years later (regression 3) they were 2.18 log points $(\$ 8.85)$ larger. This pattern is similar in regressions 4 and 5 in Table 4, where we consider pairs of countries that had containerized by 1978 and measure trade values in 1978 and 1983.

Table 4: Trade value regressions

\begin{tabular}{|c|c|c|c|c|c|}
\hline \multirow{5}{*}{$\begin{array}{l}\text { Not traded in } \\
\text { Dep. Var. Import } \\
\text { Status in year: } \\
\text { Containerization } \\
\text { date between }\end{array}$} & 1 & 2 & 3 & 4 & 5 \\
\hline & OLS & OLS & OLS & OLS & OLS \\
\hline & 1968 & 1968 & 1968 & 1968 & 1968 \\
\hline & 1973 & 1978 & 1983 & 1978 & 1983 \\
\hline & $1966-1973$ & $1966-1973$ & $1966-1973$ & $1966-1978$ & $1966-1978$ \\
\hline Cont $_{i j}$ & $\begin{array}{c}-0.45 \\
(0.282)\end{array}$ & & & $\begin{array}{c}0.10 \\
(0.801)\end{array}$ & \\
\hline L5. Cont & & $\begin{array}{c}0.06 \\
(0.820)\end{array}$ & & & $\begin{array}{c}2.02^{* * *} \\
(0.430)\end{array}$ \\
\hline L10. Cont ${ }_{i j}$ & & & $\begin{array}{c}2.18^{* * *} \\
(0.417)\end{array}$ & & \\
\hline$N$ & 80316 & 61327 & 48085 & 80316 & 67074 \\
\hline R-squared & 0.067 & 0.106 & 0.163 & 0.100 & 0.153 \\
\hline Controls & $\begin{array}{l}\text { Importer, } \\
\text { exporter, } \\
\text { product }\end{array}$ & $\begin{array}{c}\text { Importer, } \\
\text { exporter, } \\
\text { product }\end{array}$ & $\begin{array}{c}\text { Importer, } \\
\text { exporter, } \\
\text { product }\end{array}$ & $\begin{array}{l}\text { Importer, } \\
\text { exporter, } \\
\text { product }\end{array}$ & $\begin{array}{l}\text { Importer, } \\
\text { exporter, } \\
\text { product }\end{array}$ \\
\hline
\end{tabular}

Standard errors in parentheses

* $\mathrm{p}<0.05, * * \mathrm{p}<0.01, * * * \mathrm{p}<0.001$

Dependent variable is the log of trade flows. Sample restricted to temperature sensitive and containerizable products. All regressions restrict the sample to only include country-product combinations for which there was no trade in 1968. All regressions control for FTA, GATT membership, border, common language, distance, colonial links, trade preferences. Dummies: $i$ stands for importer, $j$ for exporter, $k$ for product. We cluster standard errors by country-pair (ij).

\subsection{Robustness checks}

Before moving on to consider various extensions of the main hypothesis, in this section of the paper we establish the robustness of the main results in Table 3. We consider adjustments to the estimation method, the effect of possible omitted variables, the measure of temperature sensitivity and the measure of 
containerizability, the Kehoe and Ruhl (2013) definition of new trades and the possible use of air-freight. All of our robustness estimates are reported in Table 5.

In regressions 1 and 2 in Table 5 we consider the possibility of biases that stem from omitted bilateralproduct specific factors that explain the increase in bilateral trade between containerized countries. In order to continue to identify the effects of containerization in such a regression we pool the data between 1968 and 1978 and estimate a model with i-j-k fixed effects. This is reported in regression 1 . In regression 2 we additionally add time effects to explore whether there were common period specific shocks that might explain our results. We find that there is a modest impact on the magnitude of the estimated effect of containerization in these regressions and the main results carry over.

In regressions 3 and 4 we compare the effects of containerization on products classified by Rytter (2009) as either sensitive (group 3) or very sensitive (group 4). The point estimates for the two groups are identical, suggesting that the results we have derived so far are not sensitive to this choice.

In the next two regressions we change the definition of the containerizability of products. According to Bernhofen et al. (2016), products can be classified as being 'suitable for containers' (Class A), 'slightly suitable for containers' (Class B), or 'non-suitable for containers' (Class C). Thus far we have defined containerizable products to be products from either Class A or Class B. In regression 5, we redefine containerizable products to be Class A products only. Again this has no bearing on the conclusions that we have drawn about the effects of containerization on TSPs. In regression 6, we consider the effect of dropping small countries, on the basis that these countries do not have the production capacity to produce all of the potential products imported by the OECD countries with little changes in the results. However, when restricting the sample to OECD trade in regression 7 , the coefficient jumps to 0.254 , which is not unexpected. Regression 8 reports estimations using a probit rather than a linear probability model, with relatively minor changes in the size of the coefficient.

In regression 9, we follow the Kehoe and Ruhl (2013) definition of new products as those that accounted for less than $10 \%$ of trade volumes in 1968. In other words, a product $k$ is considered to be untraded in 1968 if it falls in the bottom decile of trade between countries $i$ and $j$. This has no impact on the effect of the adoption of the container that we find and indicate the results are not dependent on using a trade value of zero in 1968 to measure the extensive margin. Defining new trades in a manner consistent with Kehoe and Ruhl (2013) suggests that containerization increased the probability of new products being traded by $8.8 \%$.

Regression 10 revisits the issue of air-freight. While clearly an important presence in the modern international delivery of high-value TSP such as pharmaceuticals, the historical evidence indicates that the technologies necessary to maintain the integrity of the products were not widely used during the time period that we study. That is, our results are unlikely to capture the effect of advances in the use of air-freight rather than the containerization of ships. Nevertheless we investigate this further in regression 10 by restricting the analysis to products for which air freight in not typically used for transportation. To construct this measure we use U.S. Census data for 2003, and which includes information on the method of delivery (container, air-freight, truck) and calculate the proportion of the value of goods imported into the US using these different modes of transport. We define as air-freight intensive those products for which this value is higher than $50 \%$. We choose 2003 as the year to construct this measure in order to exclude as many products as possible where trade in 1968 might have been affected by the development of this alternative transportation technology. Regression 10 shows that the exclusion of air-freight intensive products has little bearing upon our results.

Finally, regression 11 estimates equation (1) employing $i k$ and $j k$ fixed effects rather than estimating it with importer, exporter and product fixed effects separately. This can be interpreted as capturing the 'equivalent' of multi-lateral resistance in the context of our empirical specification. Interestingly, this specification increases both the magnitude of point estimate of our container variable the R square value. 
Table 5: Robustness

\begin{tabular}{|c|c|c|c|c|c|c|c|c|c|c|c|}
\hline Regression no. & 1 & 2 & 3 & 4 & 5 & 6 & 7 & 8 & 9 & 10 & 11 \\
\hline Not traded in: & 1968 & 1968 & 1968 & 1968 & 1968 & 1968 & 1968 & 1968 & 1968 & 1968 & 1968 \\
\hline $\begin{array}{l}\text { Dep. Var. } \\
\text { Import Status } \\
\text { in: }\end{array}$ & $\begin{array}{c}1968- \\
1978\end{array}$ & $\begin{array}{c}1968- \\
1978\end{array}$ & 1973 & 1973 & 1973 & 1973 & 1973 & 1973 & 1973 & 1973 & 1973 \\
\hline \multirow[t]{2}{*}{$\begin{array}{l}\text { Containerization } \\
\text { date between: }\end{array}$} & $\begin{array}{c}1966- \\
1978\end{array}$ & $\begin{array}{l}1966- \\
1978\end{array}$ & $\begin{array}{l}1966- \\
1973\end{array}$ & $\begin{array}{l}1966- \\
1973\end{array}$ & $\begin{array}{c}1966- \\
1973\end{array}$ & $\begin{array}{l}1966- \\
1973\end{array}$ & $\begin{array}{l}1966- \\
1973\end{array}$ & $\begin{array}{l}1966- \\
1973\end{array}$ & $\begin{array}{l}1966- \\
1973\end{array}$ & $\begin{array}{l}1966- \\
1973\end{array}$ & $\begin{array}{l}1966- \\
1973\end{array}$ \\
\hline & Panel & Panel & $\begin{array}{l}\text { Sensitive } \\
\text { TSP }\end{array}$ & $\begin{array}{l}\text { Very- } \\
\text { sensitive } \\
\text { TSP } \\
\end{array}$ & $\begin{array}{c}\text { Measure of } \\
\text { containerizability }\end{array}$ & $\begin{array}{c}\text { Drops } \\
\text { small } \\
\text { countries } \\
\end{array}$ & $\begin{array}{l}\text { OECD } \\
\text { trade only }\end{array}$ & Probit & $\begin{array}{l}\text { Bottom } \\
10 \% \text { in } 68\end{array}$ & $\begin{array}{c}\text { Not air } \\
\text { intensive }\end{array}$ & jk FE \\
\hline Cont $_{i j}$ & $\begin{array}{c}0.077^{* * *} \\
(0.002)\end{array}$ & $\begin{array}{c}0.047^{* * *} \\
(0.002)\end{array}$ & $\begin{array}{c}0.087^{* * *} \\
(0.014)\end{array}$ & $\begin{array}{c}0.087^{* * *} \\
(0.011)\end{array}$ & $\begin{array}{c}0.089 * * * \\
(0.012)\end{array}$ & $\begin{array}{c}0.077^{* * *} \\
(0.013)\end{array}$ & $\begin{array}{c}0.254^{* * *} \\
(0.018)\end{array}$ & $\begin{array}{c}0.072 * * * \\
(0.024)\end{array}$ & $\begin{array}{c}0.088^{* * *} \\
(0.013)\end{array}$ & $\begin{array}{c}0.089 * * * \\
(0.011)\end{array}$ & $\begin{array}{c}0.108 * * * \\
(0.015)\end{array}$ \\
\hline$N$ & $1,811,259$ & $1,811,259$ & 214,498 & 389,255 & 485,241 & 377,372 & 69,246 & 603,753 & 598,969 & 536511 & 603753 \\
\hline$R$-squared & 0.139 & 0.147 & 0.214 & 0.138 & 0.163 & 0.162 & 0.211 & 0.120 & 0.160 & 0.153 & 0.345 \\
\hline Controls & $i j k$ & $i j k, t$ & $i, j, k$ & $i, j, k$ & $i, j, k$ & $i, j, k$ & $i, j, k$ & & $i, j, k$ & $i, j, k$ & $i k, j k$ \\
\hline
\end{tabular}

Standard errors in parentheses

Dependent variable is import status in year $t$ of product $k$ from country $j$ into country $i$. Sample restricted to temperature sensitive and containerizable products. All regressions restrict the sample to only include country-product combinations for which there was no trade in 1968. All regressions control for free trade agreements (FTA), GATT membership, border, common language,

distance, colonial links, trade preferences. Dummies: $i$ stands for importer, $j$ for exporter, $k$ for product, and $t$ for year. Regression 6 includes only partner countries that trade in at least $10 \%$ of all possible product categories. Regression 9 redefines zero-trade flows as in Kehoe and Ruhl (2013). Regression 10 drops air-intensive products. Air-intensive products are products that are more than $50 \%$ by value traded by air by the US in 2003 . 


\section{Extensions}

\subsection{Spillovers from non-reefer trade}

The history of the reefer trade over our time period makes clear that reefer boxes were first made available on container ships that primarily served general cargo. The effect of containerization on trade in TSP is therefore likely to differ according to the availability of general cargo trade. Larger volumes of trade in non-TSP meant more or larger container ships, increasing the availability of electrical points necessary for reefer container on those routes. We label this as non-reefer trade and proxy for this using total trade flows in containerizable products (other than TSP) between countries $i$ and $j$ at time $t-1$. We also include an interaction term of the bilateral-containerization and non-reefer trade variables.

Given the reliance of reefer containers to the presence of container ships on a route we would anticipate a difference in the effect on the probability of trade in TSP between country-pairs with no trade (zero trade) versus positive trade in non-TSP containerizable products. We therefore construct a zero-one dummy (non-reefer dummy), equal to 1 when the trade flow in containerizable non-TSP products is positive and zero otherwise. ${ }^{25}$ We again include this in the regression along with an interaction with the containerization variable. In Table 6 regression 1, we report the results for country pairs that containerize by 1973 and in regression 2 the results for those countries that containerize between 1966 and 1978. That we condition on the value of nonreefer trade, as we explain below, these dummies capture the effect on trade in TSP when the value of nonreefer trade is small.

We find a consistent pattern across these two regressions. The reference category in these regressions is non-containerized country-pairs where there is no trade in general cargo (non-reefer products). For countrypairs that had both adopted the technology by 1973 and 1978 but there was no trade in non-reefer products the probability that new trades occurred was $2.8 \%$ and $3.7 \%$ higher respectively (given by the coefficient on the cont $_{i j}$ variable) than the reference group. Containerization would appear to have some small benefits even when there was no established trade between those countries in non-reefer products. Where there was positive bilateral trade in non-reefer products the results are more complicated, they are negative for small trade flows and positive for larger flows. That reefer container slots could also be used for standard containers, but not vice-versa, may suggest that when competition for container slots was high, as might occur when volumes of trade were small, reefer containers were squeezed out. When trade flows were much larger this is less likely to occur. In support of this view the interaction terms of the non-reefer dummy and the $\log$ (nonreefer trade) with the bilateral container variable are statistically significant in both regressions. Of particular interest in these results is the finding that the probability of trade by both containerized and non-containerized countries is affected by non-reefer trade, but the effect is over $4 \frac{1}{2}$ times larger for containerized country-pairs in regression 1 (the coefficient is 0.014 compared to 0.03). In regression 2 this result is even more stark; the volume of trade in non-reefer products between pairs of countries that were not containerized had no effect on trade in temperature sensitive products. This would seem to confirm a strong spillover effect from non-reefer containerized trade.

To provide a quantitative assessment of the non-linearity consider a hypothetical country-pair with a bilateral trade flow of just $\$ 1$ (for non-reefer trade). For this pair of countries the probability of new trade in TSPs occurring by 1973 is $16.8 \%$ lower than the reference group (given by the sum of the coefficient on the cont $_{\mathrm{ij}}+$ non-reefer dummy $\mathrm{ijt}_{\mathrm{it}}+$ non-reefer dum $_{\mathrm{ijt}}{ }^{*}$ cont $_{\mathrm{ijt}}$ variables). This effect remains negative until logged trade flows reaches $9.82(\$ 18,463)$. Beyond this level of trade containerized non-reefer trade serves to act positively on the probability of trade flows. Over $86 \%$ of bilateral trade flows are above this value in the data $(60 \%$ when the zero-flows are also included). The median value of the log of positive non-reefer trade flows in 1973 was

\footnotetext{
${ }^{25}$ Even when trade flows are aggregated to the level of bilateral trade it is well known that they contain many zeros (references). This is also true in our data. In 1973, 31\% of observations have zero trade flows recorded between all country-pairs. By 1978 this figure has dropped to $21 \%$.
} 
$13.6(\$ 806,130)$. At this value of trade the probability of trade in TSPs is an estimated $6.4 \%$ higher than the reference category. A standard deviation increase (an increase of $2.85 \mathrm{log}$ points) from the mean would raise this probability to $11.2 \%$. From the results for 1978 the turning point in the data occurs at 9.2 (logged trade), while at the mean value of non-TSP trade the probability of new trade in TSPs is $7.3 \%$ higher than the reference category.

As already mentioned there is also an effect from the non-reefer trade for TSP products in countries that did not-containerize. Given the absence of reefer containers on traditional (non-container) general cargo ships this is likely to capture the effect of short-distance trade in TSP where the need for reefer containers is less pressing; temperatures could be controlled sufficiently by the insulation of trucks over short travel distances for example. The pattern of the effects mirrors that for trade between containerized countries; negative at small values of trade and positive at larger values, although the location of the turning point differs. When bilateral trade in non-TSP products is positive we find that the probability of new trade in TSPs is positive only for bilateral trade volumes in non-TSP products above $\$ 17,365,569$ (16.67 log points). Only around $7 \%$ of observations for this group are above this cut-off value. At the mean value of trade (logged bilateral trade $=$ 13.1) the probability is $1.1 \%$ lower than the reference group indicating that in general trade in temperature sensitive products was less likely when countries were not containerized.

Table 6: Spillovers from non-TSP trade

\begin{tabular}{|c|c|c|}
\hline $\begin{array}{l}\text { Regression no. } \\
\text { Not traded in: } \\
\text { Dep. Var. Import Status in: } \\
\text { Containerization date: }\end{array}$ & $\begin{array}{c}1 \\
1968 \\
1973 \\
1966-1973\end{array}$ & $\begin{array}{c}2 \\
1968 \\
1978 \\
1966-1978\end{array}$ \\
\hline Cont $_{i j}$ & $\begin{array}{c}0.028^{* *} \\
(0.012)\end{array}$ & $\begin{array}{c}0.037 * * * \\
(0.010)\end{array}$ \\
\hline Non-reefer dummy ${ }_{i j}$ & $\begin{array}{c}-0.050 * * * \\
(0.004)\end{array}$ & $\begin{array}{c}-0.024^{* * *} \\
(0.005)\end{array}$ \\
\hline Cont $_{i j}{ }^{*}$ Non-reefer dummy ${ }_{i j}$ & $\begin{array}{c}-0.146 * * * \\
(0.015)\end{array}$ & $\begin{array}{c}-0.141 * * * \\
(0.011)\end{array}$ \\
\hline $\log (\text { non-reefer trade })_{i j}$ & $\begin{array}{c}0.003 * * * \\
(0.000)\end{array}$ & $\begin{array}{c}0.000 \\
(0.000)\end{array}$ \\
\hline Cont $_{i j}{ }^{*} \log (\text { non-reefer trade })_{i j}$ & $\begin{array}{c}0.014^{* * *} \\
(0.001)\end{array}$ & $\begin{array}{c}0.013^{* * *} \\
(0.001)\end{array}$ \\
\hline$N$ & 603,753 & 603,753 \\
\hline $\begin{array}{l}\text { R-squared } \\
\text { Controls }\end{array}$ & $\begin{array}{l}0.214 \\
\text { Importer, } \\
\text { exporter, } \\
\text { product }\end{array}$ & $\begin{array}{l}0.207 \\
\text { Importer, } \\
\text { exporter, } \\
\text { product }\end{array}$ \\
\hline \multicolumn{3}{|c|}{$\begin{array}{l}\text { Standard errors in parentheses } \\
* p<0.05, * * p<0.01, * * * p<0.001 \\
\text { Dependent variable is import status in year } t \text { of product } k \text { from country } j \text { into country } i \text {. Sample restricted to temperature sensitive } \\
\text { and containerizable products. All regressions restrict the sample to only include country-product combinations for which there was } \\
\text { no trade in 1968. All regressions control for free trade agreements (FTA), GATT membership, border, common language, distance, } \\
\text { colonial links, trade preferences as well as importer, exporter, and product dummies. We cluster standard errors by country-pair (ij). } \\
\text { Non-reefer dumm } y_{i j} \text { controls for non-zero trade in non-TSP products between countries } i \& j \text {. Variable non-reefer trade } e_{i j} \text { controls for } \\
\text { total trade value in non-TSP products between countries } i \& j \text {. }\end{array}$} \\
\hline
\end{tabular}




\subsection{Alternative counterfactual}

Our main finding that technological change can explain changes to the extensive margin of trade could be contested on the grounds that we are capturing other wider changes at the bilateral level that occur for containerized countries, say because of changes in demand or non-container related policy factors that make trade easier. The governments of early adopters of the container technology are different from those of lateadopters and they may undertake a range of policy actions that seek to lower trade costs. While we control for a number of country and policy factors within the regressions we cannot completely rule out this possibility and the effect of this selection bias are not removed by first differencing the data. Given the assumed bilateral nature of these omitted variables, we approach this question by instead creating a new counterfactual that would rule out selection bias of this form.

To construct this counterfactual we use information on the non-containerizability of some temperature sensitive products. That is we restrict the sample to bilateral-pairs that containerize between 1966 and 1973 and then test whether the containerizability of products mattered or not for whether they become traded in 1968. The effects of the container are now identified, not from differences relative to non-containerized pairs of countries but from differences in the suitability of some products to be transported inside of a container. ${ }^{26} \mathrm{~A}$ final point of note with regard to this counterfactual is that there is some evidence that they were positively affected by the emergence of airfreight over this time period. Drewry (1990) notes how live-animals were transported by air in large numbers. The counterfactual using this group might therefore be thought of as capturing the possibility that containerizable TSPs would have been transported by air rather than sea much earlier if reefer-containers had not been invented.

We again begin by providing information for the parallel trends assumption. We find that of the 400,387 containerizable TSPs that were not traded in 1964, 5.3\% start to be imported by countries which containerize in the future, whereas of the 14,331 non-containerizable products in these same countries or $4.8 \%$ start to be imported by 1968. The rate of change in the extensive margin is again very similar to that observed for the control group when we study what happens to trade flows between countries in the postcontainerization period. We again also accept that containerizability of TSPs amongst future adopters of the container does not help to predict which products start to be traded between 1964 and 1968 in regression 1 in Table $7 .{ }^{27}$ Again this would lend support to the assumption that the parallel trends assumption holds within the data.

Having established this we estimate the regression defining treatment according to whether containerization occurred in the period 1966-1973 (regression 2) or 1966-1978 (regression 3). We find that defining treatment according to the containerizability of products again yields evidence of an effect from containerization, although the effect is smaller compared to earlier regressions. This suggests that selection bias mattered little for our earlier results. Containerizable TSP products were more likely to be imported compared to non-containerizable TSP products within country-pairs that had adopted the container in regression 2 , with an even stronger effect found in regression 3. The magnitudes of these effects are $2.5 \%$ in regression 2 and $4.3 \%$ higher in regression 3.

Why might the effect be larger in the later time period? We tested whether the abolition of most tariffs and non-tariff barriers to live animal imports by the EEC from the early 1970s to 1974/5 (United Nations, 1985) could explain increased trade amongst live-animal exports up to 1973. Defining the EEC to include the original 6 members (Belgium, France, Germany, Italy, Luxembourg, Netherlands) we find that whilst non-containerizable TSP trade by these countries was more likely, the effect of the container variable was both similar in magnitude to regression 2 and remained statistically significant (coefficient (t-statistic): 0.020 (4.01)). We choose not to report this regression.

\footnotetext{
${ }^{26}$ Given the time invariant nature of this product characteristic we exclude the product-effects from the regression.

${ }^{27}$ We find similar results if we restrict the analysis to include only countries that containerize between 1966 and 1973 , or between 1966 and 1978.
} 
In earlier tables the results suggested that there might have been some initial adjustment in the behavior of the earliest containerizers and the effects of containerization took time to materialize. In regression 4 we compare the effects on products for country pairs that containerized at any point from 1966 to 1983 . Here we again find a significant positive effect from containerization that is of a similar magnitude to when containerization occurs between 1966 and 1978. We replicate the analysis in regressions 5 and 6 but allowing for a longer period of adjustment. These regressions are similar in design to those presented as regressions 2 and 3 in Table 3 . In regression 5 we find evidence that containerizable products for country-pairs that had adopted the container by 1973 were $7.1 \%$ more likely to be imported in 1978 compared to non-containerizable products. By 1983 we find this effect to be $8.1 \%$ (regression 6).

Table 7: Alternative counterfactual

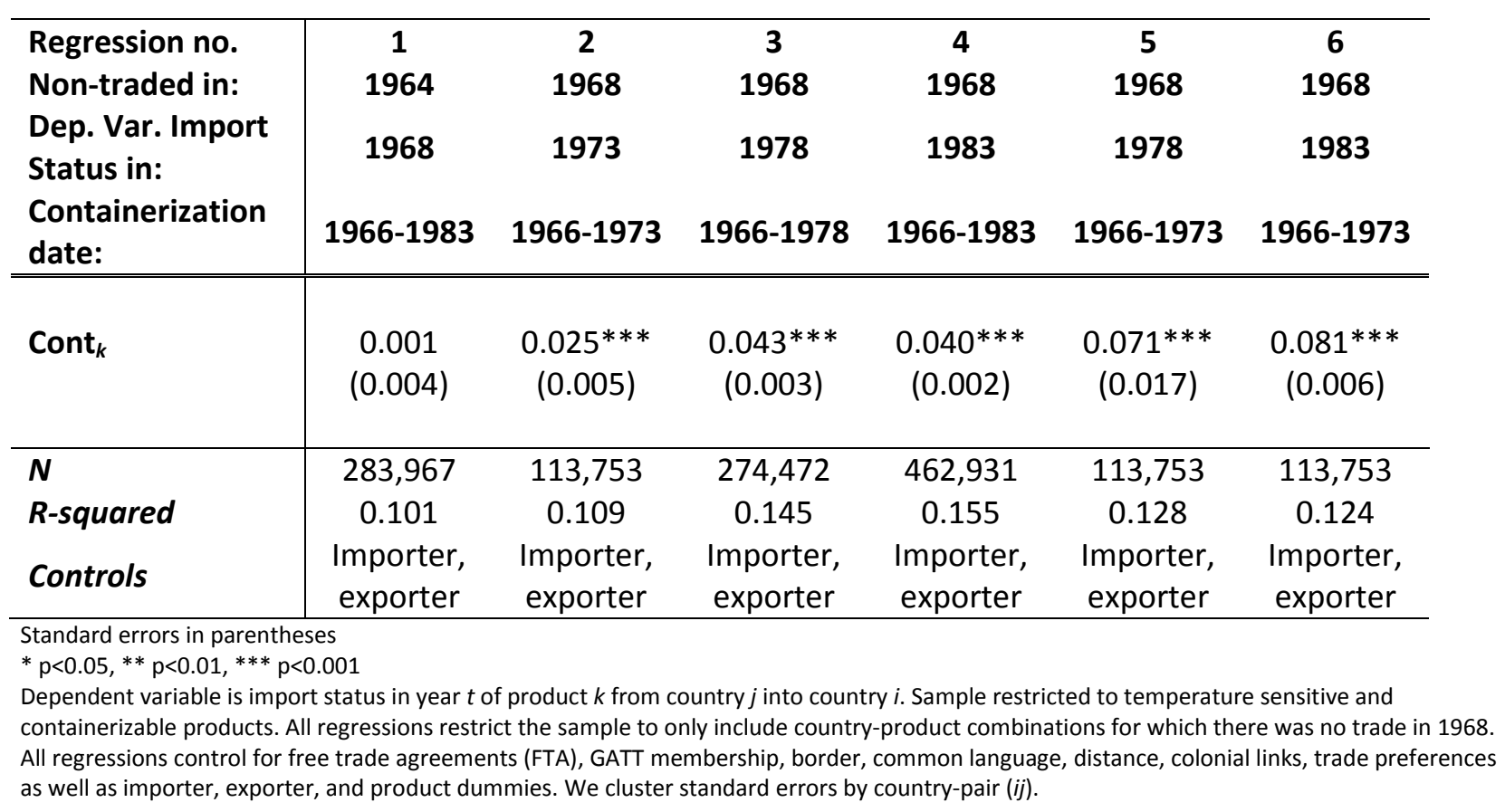

\section{Conclusion}

Our paper contributes to an emerging literature that examines the impact of changes in economic fundamentals on the extensive margin of trade. While existing papers have primarily focused on structural changes resulting from tariff reductions or other trade policy changes, our paper breaks new ground by investigating the impact of a fundamental change in shipping technology - the 1960s/70s container revolutionon the emergence of new trade.

Our empirical specification is rooted in a historical narrative which suggests that the emergence of new trade in non-bulk temperature-sensitive products was an unanticipated effect of the container revolution. Exploiting bilateral data on container adoption and trade at the product level, we are able to provide empirical evidence for the parallel trend assumption which validates the use of late or non-adopters as a counterfactual in our treatment approach. Using a battery of different specifications, we provide robust evidence for the claim that the container revolution caused new trade across bilateral trading relationships. 


\section{References}

Agriculture Organization of the United Nations. Animal, Plant, \& Food Legislation Section, 1985. Legislation Controlling the International Beef and Veal Trade (No. 36). Food \& Agriculture Org.

Arduino, G. and Parola, F., 2010. Cold Chain In The Shipping Industry Bulk Versus Container In The Banana Trade. 12th World Conference on Transport Research.

Arkolakis, Costas, Demidova, Svetlana, Klenow, Peter J, Rodríguez-Clare, Andrés, 2008. Endogenous variety and the gains from trade. American Economic Review 98 (May), 444-450.

Bernhofen, Daniel M., El-Sahli, Zouheir, Kneller, Richard, 2016. Estimating the effects of the container revolution on world trade. Journal of International Economics 98, 36-50.

Broda, Christian, Weinstein, David, 2006. Globalization and the gains from variety. Quarterly Journal of Economics 121, 541-585.

Containerisation International, 1970-1992. Various issues. National Magazine Co. Ltd, London.

Debaere, Peter, Mostashari, Shalah, 2010. Do tariffs matter for the extensive margin of international trade? An empirical analysis. Journal of International Economics (81), 163-169.

Drewry Shipping Consultants Ltd, 1983. Reefer Container Market: Developments in Perishable Cargo Shipping and Trades.

Drewry Shipping Consultants Ltd, 1988. The Reefer Market Trends and Prospects in Refrigerated Cargo Trade and Shipping 1985 to 1995.

Drewry Shipping Consultants Ltd, 1990. Reefer Container Market: Progress in the Containerised Transport of Perishable Commodities 1987-2000.

Drewry Shipping Consultants Ltd, 1992. Reefer Shipping: Global Prospects for Refrigerated Cargo Shipping and Trade to 2005.

El-Sahli, Zouheir, Upward, Richard, 2015. Off the waterfront: the long -run impact of technological change on dock workers. GEP discussion paper 15-06.

Feenstra, Robert C., 1994. New product varieties and the measurement of international trade. American Economic Review 84, 157-77.

Felbermayr, Gabriel, Kohler, Wilhelm, 2006. Exploring the intensive and extensive margins of world trade, Review Of World Economics 142(4), 642-674.

Flam, H. and Nordström, H., 2006. Euro Effects on the Intensive and Extensive Margins of Trade (No. 1881). CESifo Group Munich.

Gordon, Robert, 1990. The Measurement of Durable Goods Prices. University of Chicago Press.

Hummels, D. and Klenow, P.J., 2005. The variety and quality of a nation's exports. The American Economic Review, 95(3), pp.704-723.

Hummels, D., 2007. Transportation costs and international trade in the second era of globalization. The Journal of Economic Perspectives, 21(3), pp.131-154.

Kehoe, Timothy and Ruhl, Kim J. ,2013. How Important Is the New Goods Margin in International Trade? Journal of Political Economy 121 (2), 358-392.

Levinson, Mark, 2006. The Box: How the Shipping container Made the World Smaller and the World Economy Bigger. Princeton University Press. 
McKinsey Co., 1967. Containerization: the key to low-cost transport. A report for the British Transport Docks Board.

McKinsey Co., 1972. Containerization: A 5-year balance sheet.

Mokyr, Joel, 1990. The Lever of riches: technological creativity and economic progress. Oxford University Press.

Mukerji, P., 2009. Trade liberalization and the extensive margin. Scottish Journal of Political Economy, 56(2), pp.141-166.

Rua, Gisela, 2014. Diffusion of containerization. Finance and Economics Discussion Series Staff working paper 2014-88. Federal Reserve Board, Washington DC.

Skallerud, Kåre, Olsen, Svein Ottar 2011. Export Marketing Arrangements in Four New Zealand Agriculture Industries: An Institutional Perspective. Journal of International Food \& Agribusiness Marketing 23, :310-329.

Tayssa Rytter for TFK- TransportForsK AB, 2009. Transport of Temperature Sensitive Goods in Europe: Definition, Limitations, Flow Analysis and Case Studies. (ENGINEERING REPORT). 


\section{Appendix 1 Countries in the Sample}

Algeria, Angola, Argentina, Australia, Austria, Bahamas, Bahrain, Bangladesh, Belgium-Luxembourg, Belize, Benin, Bermuda, Bolivia, Botswana, Brazil, Brunei Darussalam, Bulgaria, Burkina Faso, Burundi, Cambodia, Cameroon, Canada, Central African Republic, Chad, Chile, China, Chinese Taipei (Taiwan), Colombia, Comoros, Congo, Costa Rica, Cuba, Cyprus, Democratic Republic of Congo, Denmark, Djibouti, Dominican Republic, Ecuador, Egypt, El Salvador, Equatorial Guinea, Ethiopia, Fiji, Finland, Former Burma, Former Czechoslovakia, Former USSR, Former Yugoslavia, France, French Guiana, Gabon, Gambia, Germany, Ghana, Greece, Guadeloupe, Guatemala, Guinea, Guinea-Bissau, Guyana, Haiti, Honduras, Hong Kong, Hungary, Iceland, India, Indonesia, Iran, Iraq, Ireland, Israel, Italy, Ivory Coast, Jamaica, Japan, Jordan, Kenya, Kiribati, Korea, Kuwait, Lao People's Democratic Republic, Lebanon, Lesotho, Liberia, Libya, Madagascar, Malawi, Malaysia, Mali, Martinique, Mauritania, Mexico, Mongolia, Morocco, Mozambique, Nepal, Netherlands, Netherlands Antilles, New Caledonia, New Zealand, Nicaragua, Niger, Nigeria, Norway, Oman, Pakistan, Panama, Papua New Guinea, Paraguay, Peru, Philippines, Poland, Portugal, Qatar, Romania, Rwanda, Saint Lucia, Samoa, Sao Tome and Principe, Saudi Arabia, Senegal, Sierra Leone, Singapore, Somalia, South Africa, Spain, Sri Lanka, Sudan, Surinam, Sweden, Switzerland, Syria, Thailand, Togo, Tonga, Trinidad and Tobago, Tunisia, Turkey, Uganda, United Arab Emirates, United Kingdom, Tanzania, United States, Uruguay, Venezuela, Vietnam, Yemen, Zambia, Zimbabwe 


\section{Appendix 2 Containerization Data}

Panel A: Countries that containerize by port or rail 1966-1983 (115 countries)

\begin{tabular}{|c|c|c|c|c|c|}
\hline \multirow{4}{*}{$\begin{array}{l}1966 \\
1968\end{array}$} & Germany $(\mathrm{P})^{*}$ & Netherlands $(\mathrm{P})^{*}$ & $\mathrm{UK}(\mathrm{P})(\mathrm{R})^{*}$ & USA(P)* & India (R) \\
\hline & Australia(P)* & Austria(R)* & Belgium $(\mathrm{P})^{*}$ & Canada $(\mathrm{P})^{*}$ & $\operatorname{Denmark}(P)^{*}$ \\
\hline & France $(P)^{*}$ & Hungary(R) & Ireland(R)* & Italy $(\mathrm{P})^{*}$ & Taiwan(P) \\
\hline & Spain $(R)^{*}$ & Sweden $(R)^{*}$ & Switzerland(R)* & & \\
\hline 1969 & Finland $(P)^{*}$ & Yugoslavia(R) & $\operatorname{Japan}(\mathrm{P})^{*}$ & Norway $(\mathrm{R})^{*}$ & Portugal(P)* \\
\hline 1970 & $\begin{array}{l}\text { Hong Kong }(P) \\
\text { Singapore }(P)\end{array}$ & USSR(R) & Greece $(P)^{*}$ & Israel(P) & Romania(R) \\
\hline 1971 & Ivory Coast(P) & New Zealand(P)* & Philippines(P) & Poland(P) & Trinidad(P) \\
\hline 1972 & Bulgaria(R) & Czechoslovakia(R) & & & \\
\hline 1973 & Bahamas(P) & $\operatorname{Brazil}(\mathrm{P})$ & Iceland $(P)^{*}$ & Jamaica(P) & Malaysia(P) \\
\hline 1974 & $\begin{array}{l}\text { Cameroon }(P) \\
\text { South Africa(P) }\end{array}$ & Chile(P) & Colombia(R) & Nigeria(P) & Panama(R) \\
\hline 1975 & Thailand(P) & Honduras(P) & Indonesia(P) & Korea Rep(P) & Peru(P) \\
\hline 1976 & $\begin{array}{l}\text { Argentina(P) } \\
\text { Saudi Arabia(P) }\end{array}$ & $\begin{array}{l}\text { Benin(P) } \\
\text { UAE }(P)\end{array}$ & Kenya(P) & Mexico(P) & N. Caledonia(P) \\
\hline 1977 & $\begin{array}{l}\text { Bahrain(P) } \\
\text { Kuwait(P) }\end{array}$ & $\begin{array}{l}\text { Cyprus(P) } \\
\text { Lebanon(P) }\end{array}$ & $\begin{array}{l}\text { Ghana(P) } \\
\text { Morocco(P) }\end{array}$ & $\operatorname{Iran}(P)$ & Jordan(P) \\
\hline 1978 & $\begin{array}{l}\text { Ecuador(P) } \\
\text { Mozambique(P) }\end{array}$ & $\begin{array}{l}\text { Egypt(P) } \\
\text { Oman }(\mathrm{P})\end{array}$ & $\begin{array}{l}\text { Tanzania(P) } \\
\text { P. N. Guinea(P) }\end{array}$ & $\begin{array}{l}\text { Haiti(P) } \\
\text { Samoa(P) }\end{array}$ & $\begin{array}{l}\text { Iraq }(\mathrm{P}) \\
\text { Sierra Leone(P) }\end{array}$ \\
\hline 1979 & $\begin{array}{l}\text { Algeria(P) } \\
\text { El Salvador(P) } \\
\text { Qatar(P) }\end{array}$ & $\begin{array}{l}\text { Angola(P) } \\
\text { Syria(P) } \\
\text { Sri Lanka(P) }\end{array}$ & $\begin{array}{l}\text { China(P) } \\
\text { Neth.Antilles(P) }\end{array}$ & $\begin{array}{l}\text { Congo(P) } \\
\text { Nicaragua(P) }\end{array}$ & $\begin{array}{l}\text { Djibouti(P) } \\
\text { Pakistan(P) }\end{array}$ \\
\hline 1980 & $\begin{array}{l}\text { Guatemala(P) } \\
\text { Uruguay }(\mathrm{P})\end{array}$ & Liberia(P) & Libya(P) & Madagascar(P) & Sudan(P) \\
\hline 1981 & $\begin{array}{l}\text { Brunei(P) } \\
\text { Dominican Rep(P) } \\
\text { Tunisia(P) }\end{array}$ & $\begin{array}{l}\text { Bangladesh }(P) \\
\text { Fiji }(P) \\
\text { Turkey }(P)^{*}\end{array}$ & $\begin{array}{l}\text { Belize(P) } \\
\text { Guadeloupe(P) }\end{array}$ & $\begin{array}{l}\text { Costa Rica(P) } \\
\text { Togo(P) }\end{array}$ & $\begin{array}{l}\text { Dem.Rep.Congo(P) } \\
\text { Venezuela(P) }\end{array}$ \\
\hline 1982 & Gambia(P) & Kiribati(P) & Mauritania(P) & & \\
\hline 1983 & Bermuda(P) & Ethiopia(P) & Guinea(P) & Malta(P) & Myanmar(P) \\
\hline
\end{tabular}

$(P)$ denotes that the country containerized by port first.

(R) denotes that the country containerized by rail first.

$\left({ }^{*}\right)$ denotes that the country is an OECD country.

Panel B: Countries that do not containerize by port or rail 1966-1983 (30 countries)

\begin{tabular}{lllll}
\hline Chad & Mongolia & Senegal & Cuba & GuineaBissau \\
Nepal & Somalia & Bolivia & Eq. Guinea & Guyana \\
Bolivia & Eq. Guinea & Guyana & Niger & Suriname \\
Burkina Faso & Laos & Uganda & Burundi & French Guiana \\
Paraguay & Viet Nam & Cambodia & Malawi & Rwanda \\
Cen. African Rep & Gabon & Mali & Zambia & Zimbabwe \\
\hline
\end{tabular}




\section{Appendix 3: List of Temperature Sensitive Products (TSPs)}

00111 Bovine species pure bred, for breeding

00119 Bovine species other than pure bred breeding stock

00121 Sheep, live

00122 Goats, live

0013 Swine, live

00141 Poultry, live of a weight not exceeding 185 grammes

00149 Poultry, live of a weight exceeding 185 grammes

0015 Horses, asses, mules and hinnies, live

0019 Live animals of a kind mainly used for human food

01111 Meat of bovine animals with bone in

01112 Meat of bovine animals boneless

0112 Meat of sheep and goats, fresh, chilled or frozen

0113 Meat of swine, fresh, chilled or frozen

0114 Poultry, dead \& edible offals except liver, fresh/frozen

0115 Meat of horses, asses, etc., fresh, chilled, frozen

0116 Edible offals of animals in headings 001.1-001.5

01181 Poultry liver, fresh, chilled, frozen, salted/in brine

01189 Meat \& edible offals, fresh, chilled or frozen

0121 Bacon, ham \& other dried, salted, smoked meat/ swine

0129 Meat \& edibleoffals, n.e.s. salt.in brine dried/smok.

0141 Meat extracts and meat juices; fish extracts

0142 Sausages \& the like, of meat, meat offal or blood

0149 Other prepared or preserved meat or meat offals

0223 Milk \& cream, fresh, not concentrated or sweetened

02241 Whey

02242 Milk in powder/granul.(weight not more $1.5 \%$ of fat

02243 Milk \& cream powder (weight more than $1.5 \%$ of fat)

02249 Milk \& cream, preserved, concentrated or sweetened

0230 Butter

0240 Cheese and curd

0251 Eggs in shell

0252 Eggs not in shell

0341 Fish, fresh (live/dead) or chilled, excl.fillets

0342 Fish, frozen (excluding fillets)

0343 Fish fillets, fresh or chilled

0344 Fish fillets, frozen

03501 Fish meal fit for human consumption

03502 Cod (not in fillets), dried, whether or not salted

03503 Fish, dried, salted or in brine (other than cod)

03504 Fish, smoked (whether or not cooked)

0360 Crustaceans and molluscs, fresh, chilled, frozen etc.

0371 Fish, prepared or preserved, n.e.s. including caviar

0372 Crustaceans and molluscs, prepared or preserved

0483 Macaroni, spaghetti and similar products

05855 Tomato juice

05857 Juice of any other fruit or vegetable
04841 Bread, ships, biscuits \& other ordinary bakers wares 04842 Pastry, biscuits, cakes and other fine bakers wares 0488 Malt extract; preparations of flour etc, for infant food 0541 Potatoes, fresh or chilled, excluding sweet potatoes 0542 Beans, peas, lentils \& other leguminous vegetables 0544 Tomatoes, fresh or chilled 05451 Onions, shallots, garlic, leeks \& alliaceous veget. 05459 Vegetables, fresh or chilled, n.e.s. 05461 Vegetables, preserved by freezing, cooked or not 05462 Vegetables provisionally preserved in brine etc. 05481 Manioc, arrowroot, salep, jerusalem artichokes etc. 05482 Sugar beet, whole or sliced, fresh, dried or powdered 05484 Hop cones and lupulin

05488 Vegetables products of a kind used for human food 0561 Vegetables, dried, dehydrated or evaporated 05643 Flour, meal and flakes of potato 05645 Tapioca \& sago \& substitutes obtained from potato 05649 Flours of the leguminous vegetables and fruits 05651 Vegetables \& fruit, prepared/preserved by vinegar 05659 Vegetables prepared/preserved otherwise than by vinegar 05711 Oranges, fresh or dried

05712 Mandarins, clementines \& citrus hybrids fresh/dried 05721 Lemons and limes, fresh or dried 05722 Grapefruit, fresh or dried 05729 Citrus fruit, n.e.s., fresh or dried 0573 Bananas, fresh or dried 0574 Apples, fresh 05751 Grapes, fresh 05752 Grapes, dried (raisins)

0576 Figs, fresh or dried

05792 Pears and quinces, fresh

05793 Stone fruit, n.e.s., fresh

05794 Berries, fresh

05795 Pineapples, fresh or dried

05796 Dates, fresh or dried

05797 Avocados, mangoes, guavas, fresh or dried

05798 Other fresh fruit

05799 Other dried fruit

0582 Fruit, fruit-peel \& parts of plants, preserved by sugar 0583 Jams, fruit jellies, marmalades, fruit puree, cooked

05851 Orange juice

05852 Grapefruit juice

05853 Juice of any other citrus fruit

05854 Pineapple juice

2112 Calf skins, raw (fresh, salted, dried, pickled/limed)

2114 Goat \& kid skins, raw (fresh, salted, dried, pickled) 
05858 Mixtures of fruit or vegetable juices

05861 Fruit, preserved by freezing, no sugar added

05862 Fruit preserved by freezing, containing added sugar

05863 Fruit provisionally preserved

05864 Peel of melons or citrus fruit, fresh, frozen,

dried

05899 Fruit and nuts, prepared or preserved, n.e.s.

07111 Coffee, not roasted;coffee husks and skins

0721 Cocoa beans, whole or broken, raw or roasted

0730 Chocolate \& other food preptions containing cocoa

0741 Tea

0742 Mate

08111 Cereal straw and husks, unprepared, or chopped

08112 Mangolds, swedes, fodder roots; hay, lucerne, clover 08119 Products of veg.origin of a kind used for ani.food

08121 Bran, sharps \& other residues of maize or rice

08122 Bran, sharps \& other residues of other cereals

08123 Bran, sharps \& other residues of leguminous veget.

08141 Flours \& meals of meat/offals, unfit for human food

08142 Flours \& meals of fish, unfit for human consumption

08192 Cocoa shells, husks, skins and waste

08193 Beet-pulp bagasse \& other waste of sugar manufacture

08194 Wine lees; argol

08199 Sweetened forage; other preptions for animal feeding

09801 Homogenized composite food preparations

09802 Extracts, essences or concentrates of tea or

mate

09803 Mustard flour and prepared mustard

09804 Sauces; mixed condiments and mixed seasonings

09805 Soups and broths, in liquid, solid or powder

form

09806 Natural yeasts; prepared baking powders

09807 Vinegar and substitutes for

vinegar

09808 Edible products of animal origine, n.e.s.

09809 Food preparations, n.e.s.

11211 Grape must in fermentation/with ferment.arrested

11212 Wine of fresh grapes;grape must

11213 Vermouths \& other wines of fresh grapes flavoured

1122 Other fermented beverages n.e.s (cider, perry mead)

1123 Beer made from malt (includ.ale, stout and porter)

11241 Whisky

11242 Spirits obtained by distilling wine or grape marc

11249 Spirits and distilled alcoholic beverages, n.e.s.

2111 Bovine \& equine hides (other than calf), raw
2116 Sheep \& lamb skins with wool on, raw (fresh, salted)

2117 Sheep \& lamb skins without the wool, raw (fresh etc)

21191 Parings \& other waste of leather

21199 Hides and skins, n.e.s.raw (fresh, salted, dried etc)

21201 Mink skins, raw

21209 Other furskins, raw

2681 Seep's or lambs' wool, greasy or fleece-washed

2682 Sheep's or lambs'wool, degreased, in the mass

2683 Fine animal hair, not carded or combed

26851 Horsehair \& waste, whether or not put up on a layer

26859 Other coarse animal hair, not carded or combed

26861 Waste of sheep's/lamb's not pulled or garneted

26862 Waste of sheep's/lamb's pulled or garnetted

2687 Sheep's/lamb's wool/other aimal hair, carded/combed

29111 Bones (including of whales, seals etc) unworked, defatted

29115 Coral \& similar substances, unworked/simply prepar.

29116 Ivory, tortoise-shell, horns, antlers, hooves, etc.

29191 Human hair, unworked, wheter or not washed/scoured

29192 Pigs, hogs, and boars bristels or hair; waste

29193 Guts, bladders and stomachs of animals (no fish)

29196 Skins and other parts of birds, with their feathers

29197 Natural sponges

29198 Ambergris, castoreum etc; for pharmaceutical products

29199 Animal products nes; dead ani.unfit for human consumpt.

29261 Bulbs, tubers, tuberous roots, corms, crowns in growth

29269 Other live plants (including trees, shrubs, bushes etc)

29271 Cut flowers \& buds for bouquets/ornamental purposes

29272 Foliage, branches \& other parts, fresh, dried, dyed etc.

29291 Vegetable saps and extracts; pectic substances

29292 Vegetable materials, whether or not put up on a layer

29298 Vegetable materials and vegetable products n.e.s.

43143 Vegetable waxes, whether or not coloured

43144 Spermaceti, crude pressed or refined

51218 Glycerol (glycerin) and glycerol lyes

53222 Colouring matter of veget.origin/of animal origin

5411 Provitamins \& vitamins, narural/reprod.by synthesis

54131 Penicillins, their derivatives, not including in 541.7

54132 Streptomycins, their derivatives, not including in $\mathbf{5 4 1 . 7}$

54133 Tetracyclines, their derivatives, not including in 541.7

54139 Other antibiotics n.e.s., not including in 541.7

5414 Vegetab.alkaloids, natural/reproduced by synthesis 
54151 Insulin n.e.s., not including in 541.7

54152 Pituitary (anterior) and similar hormones, no 541.7

54153 Adrenal cortical hormones n.e.s., no 541.7

54159 Other hormones, hormon.derivatives \& other steroids

54161 Glycosid., natur./reprod.by synthesis, \& their salts

54162 Organo-therapeutic glands or other organs, dried

54164 Antisera and microbial vaccines

54165 Toxins, microbial cultures and similar products

54171 Medicaments contain.antibiotics/derivativ.thereof

54172 Medicaments contain.hormones but not antibiotics

54173 Medic.cont.alkaloids but neith.hormon.nor antibio.

54179 Medicaments containing other substances

54191 Wadding, gauze, bandages and similar articles

54199 Other pharmaceutical goods

5514 Mixtures of two or more odoriferous substances

5530 Perfumery, cosmetics and toilet preparations

5541 Soap; organic surface-active products \& preparatns

5542 Organic surface-active agents, n.e.s.

5543 Polishes \& creams, for footwear, furniture or floors

57211 Propellent powders

57212 Prepared explosives (other than propellent powders)

5722 Safety fuses, detonating fus.; percussion \& det.caps

5723 Pyrotechnic articles: (firework, railway fog etc.)

5911 Insecticides packed for sale etc.

5912 Fungicides packed for sale etc.

65117 Silk yarn etc.or waste silk put up for retail sale

7741 Electro-medical apparatus

7742 App.based on the use of $x$-rays or of radiations

87101 Refracting telescopes, prismatic or not

87102 Astronomical instruments, n.e.s.

87103 Microscopes \& diffraction apparatus

87104 Compound optical microscopes

87109 Optical appliances and instruments

87201 Dental instruments and appliances

87202 Medical, surgical, veterinary instruments

87203 Mechano-therapy appliances, massage app.etc.

8731 Gas, liquid, electricity meters

8732 Revolution counters, taximeters and the like

87411 Navigational instruments, non-electrical, compasses

87412 Surveying, hydrographic, meteorological instruments

87421 Drawing, marking-out, disc calculators and the like

87429 Parts, n.e.s.\& accessories for the instrum.of 87421

8743 Instr.non electrical, for measuring, checking flow

8744 Instr.\& app.for physical or chemical analysis

89991 Articles made from gut, bladders, tendons
87451 Balances of a sensitivity of $5 \mathrm{cg}$ or better 87452 Instruments, app.or models for demomstr. purposes

87453 Mach.\& app.for testing hardness, strength of mat.

87454 Hydrometers and similar instruments

87481 Electronic automatic regulators

87482 Electronic instr.for measuring ionizing radiations

87483 Other electronic measuring instr.\& apparatus

87484 Electro-mechanical automatic regulators

87489 Other electrical measuring instruments and app.

8749 Parts, n.e.s.accessories for 873--, 8743-, 87454, 8748

88111 Photographic, cameras

88112 Photographic, flashlight apparatus

88119 Parts of apparatus of 881.1-

88121 Cinematographic cameras, projectors, sound-rec, $<16 \mathrm{~mm}$

88122 Cinematographic cameras, projectors, sound-rec, $>16 \mathrm{~mm}$

88129 Parts of apparatus of 881.2-

88131 Image projectors, photographic enlargers \&

reducers

88139 App.\& equip.of a kind used in photo-cinematogr.lab

8821 Chemical products \& flashlight materials

88221 Photographic plates, sensitized, unexposed

88222 Film in rolls, sensitized, unexposed

88223 Paper, paperboard \& cloth, unexposed, sensitized

88224 Plates and film, sensitized, exposed

88225 Plates, un-/perforated film exposed \& developed

8830 Cinematograph film, exposed-developed, neg.or pos. 88411 Lenses, prisms, mirrors, optical elements, unmounted

88412 Lenses, prisus, mirrors, optical elements, mounted 88421 Frames and mountings, parts for spectacles etc. 88422 Spectacles, pince-nez, lorgnettes and the like

88511 Pocket watches, wrist watches

88512 Clocks with watch movements

88513 Watch movements, assembled

88514 Watch cases and parts

88521 Instrument panel clocks for vehicles, aircraft etc.

88522 Clocks, n.e.s.

88523 Time of day recording apparatus

88524 Time switches with clock or watch movement

88525 Clock movements, assembled

88526 Clock cases and cases of a similar type

88529 Clock and watch parts, n.e.s.

89605 Collections of zoological, botanical etc.interest

89606 Antiques of an age exceeding 100 years

89831 Prepared media for sound or similar recording

89832 Gramophome records, recorded tapes etc.

9410 Animals, live, n.e.s., including zoo-animals 